\title{
PERANAN WORLD WIDE FUND FOR NATURE (WWF) DALAM UPAYA KONSERVASI POPULASI BADAK JAWA DI INDONESIA
}

\author{
Eca Chairunnisa \\ Jurusan Ilmu Hubungan Internasional, Fakultas Ilmu Sosial dan Ilmu Politik, Universitas Komputer \\ Indonesia, \\ Jalan Dipatiukur No.102-116, Bandung, Indonesia \\ Email : ecachairunnisa@gmail.com
}

\begin{abstract}
This study is to examine the role of the World Wide Fund for Nature (WWF) in the Javan rhino population conservation efforts in Indonesia. Endangered Javan rhino population makes the WWF as an environmental organization that also address the issue of endangered species, participating in efforts to conserve this species. Researchers analyzed the various efforts made by the WWF conservation of Javan rhino populations in Indonesia so that the species can survive in their habitat.

The research method used in this study is the author of qualitative methods, aims to describe the facts relating to the problem under study. Most of the data collected through library research, online data retrieval, documentation, interviews and observations. The data was then analyzed with theoretical approaches associated with theories of International Relations such as the International Organizations Role Theory, and International Cooperation.

The results showed that the WWF has done his role as international organizations in dealing with the extinction of the Javan Rhino. Javan rhino population conservation programs that have been carried out by WWF in Indonesia has resulted in an increase in member javan rhino population. Thus, an important role in the conservation of WWF Indonesia's Javan rhino population.
\end{abstract}

Keywords: WWF, International Organizations, Javan Rhino

\begin{abstract}
ABSTRAK
Penelitian ini untuk mengetahui Peranan World Wide Fund for Nature (WWF) dalam Upaya Konservasi Populasi Badak Jawa Di Indonesia. Populasi badak jawa yang terancam punah membuat WWF sebagai organisasi lingkungan yang juga menangani masalah spesies langka, turut serta dalam upaya pelestarian spesies ini. Peneliti menganalisis berbagai upaya yang dilakukan oleh WWF dalam konservasi populasi badak jawa di Indonesia agar spesies ini dapat bertahan hidup di habitatnya.

Metode penelitian yang digunakan penulis dalam penelitian ini adalah metode kualitatif, bertujuan untuk menggambarkan fakta-fakta yang berhubungan dengan masalah yang diteliti. Sebagian besar data yang dikumpulkan melalui studi kepustakaan, penelusuran data online, dokumentasi, wawancara dan observasi. Data-data tersebut kemudian dianalisis dengan pendekatan teori yang berhubungan dengan Ilmu Hubungan Internasional yaitu Teori Peranan Organisasi Internasional, serta Kerjasama Internasional.

Hasil penelitian menunjukkan bahwa WWF telah melakukan perannya sebagai sebuah organisasi internasional dalam mengatasi kepunahan badak jawa. Program-program konservasi populasi badak jawa yang telah dilakukan oleh WWF di Indonesia telah membuahkan hasil dengan bertambahnya anggota populasi badak jawa. Dengan demikian, peranan WWF cukup signifikan dalam konservasi populasi badak jawa di Indonesia.
\end{abstract}

Kata Kunci: WWF, Organisasi Internasional, Badak Jawa 


\section{Pendahuluan}

\subsection{Latar Belakang}

Studi Hubungan Internasional mengalami banyak perkembangan dan perubahan seiring dengan berjalannya waktu. Studi yang awalnya hanya membahas mengenai politik internasional dan berfokus pada negara sebagai objek utama terus mengalami pergeseran dan lebih membuka diri bagi aktor non-state untuk ikut berperan dalam dunia internasional. Seperti NGO (Non-Governmental Organization), IGO (InterGovernmental Organization), MNC (Multi National Cooperation) bahkan individu juga memiliki power dan pengaruh yang kuat yang tidak dapat dikesampingkan. Aktor-aktor ini kemudian saling berinteraksi dan bekerja sama hingga terbentuk komunitas dan polapola interaksi tertentu.

Dalam dinamika studi hubungan internasional terdapat berbagai isu kontemporer yang pada awalnya lebih bersifat kepada hal yang teknis, yang kemudian berkembang menjadi agenda politik yang berimplikasi pada lahirnya pola-pola baru kerjasama internasional, dimana dalam perkembangan hubungan internasional terkini tidak lagi hanya memperhatikan aspek hubungan antara negara saja, yang hanya mencakup aspek politik, ekonomi, budaya serta aspek-aspek klasik lainnya, tetapi juga aspek lain seperti interdependensi ekonomi, hak asasi manusia, keamanan transnasional, organisasi internasional, rezim internasional dan juga masalah lingkungan hidup. Salah satu masalah lingkungan yang patut mendapat sorotan dewasa ini adalah laju penurunan populasi dan kepunahan beberapa spesies seperti badak jawa.

Salah satu hewan yang dikategorikan paling langka di Indonesia adalah badak. Dari 3 jenis badak yang hidup di Asia, 2 jenis diantaranya hidup di Indonesia. Kedua jenis badak yang terancam punah tersebut yaitu badak jawa (Rhinoceros Sondaicus) dan badak sumatera (Dicerorhenus sumatrensis). Badak jawa (Rhinoceros Sondaicus) merupakan satwa endemik khas Indonesia yang kini terancam punah. Perburuan badak bercula satu ini secara keseluruhan berhenti tahun 1990-an, tetapi pelanggaran terhadap hak atas hutan dan ekstraksi ilegal di seputar taman, serta perubahan habitat menimbulkan ancaman yang berlangsung secara terus-menerus. Tidak heran hewan ini tercantum dalam International Union for Conservation of Nature (IUCN) Red List of Threatened Species (Daftar Merah Yang Terancam dari IUCN), dan termasuk ke dalam appendix 1, yang berarti mendapat prioritas utama upaya penyelamatan dari ancaman kepunahan.

Sejak satu dekade terakhir jumlah populasi badak jawa tidak mengalami peningkatan berarti, bahkan cenderung stagnan. Menurut data yang didapat dari penelitian Taman Nasional Ujung Kulon (TNUK) yang dilakukan dalam kurun waktu 2009-2010, populasi badak jawa masih berjumlah 50 ekor.

Badak jawa, khususnya di Indonesia, merupakan satu-satunya populasi yang masih ada dan diharapkan dapat dipertahankan kelangsungan hidupnya. Badak jawa dikenal sebagai jenis kunci dalam konservasi keanekaragaman hayati. Perlindungan bagi jenis badak ini akan sangat membantu upaya perlindungan kehidupan liar lainnya, dan berbagai tipe habitat terutama di kawasan hutan Ujung Kulon. Untuk itu,

diperlukan upaya serius untuk mencegah kepunahannya, karena kepunahan satwa primadona ini dikhawatirkan dapat mendorong punahnya keanekaragaman flora dan fauna lainnya dalam kawasan Taman Nasional Ujung Kulon.

Di Indonesia badak jawa menjadi hewan yang paling banyak diburu. Catatan sejarah kehidupannya di Ujung Kulon, ternyata tidak lepas dari perburuan liar. Oleh karena itu, pemerintah Indonesia pada akhirnya pada tahun 1978 meratifikasi Convention on International Trade in Endangered Species of Wild Fauna and Flora (CITES) melalui Keputusan Presiden (Keppres) No. 43 Tahun 1978 tentang pengesahan CITES. CITES memasukkan badak jawa dalam Appendix I sebagai jenis yang jumlahnya sangat sedikit di alam dan dikhawatirkan akan punah. CITES juga mengharapkan negara lain yang menjadi sebaran badak segera berupaya melindungi badak. Hal tersebut dibutuhkan untuk membasmi perburuan dan perdagangan liar satwa langka ini.

CITES merupakan suatu konferensi yang juga memperbolehkan kehadiran organisasi-organisasi non pemerintah yang tidak mempunyai hak voting, dan menaruh perhatian pada masalah konservasi, kesejahteraan binatang, perdagangan, zoological, dan minat-minat keilmuan. Kehadiran organisasi-organisasi tersebut biasanya memberikan informasi dan data-data tambahan mengenai isu-isu lingkungan yang kompleks, serta masukan-masukan yang konstruktif dalam upaya perlindungan tumbuhan dan satwa liar. Salah satu dari organisasi tersebut adalah WWF.

World Wide Fund for Nature (WWF) sebagai sebuah organisasi non-pemerintah internasional yang menangani masalah-masalah tentang konservasi, penelitian dan restorasi lingkungan, yang dulunya bernama World Wildlife Fund dan masih menjadi nama resmi di Kanada dan Amerika Serikat. Selain itu, WWF juga menangani masalah spesies terancam punah, polusi dan perubahan iklim.

Sejak tahun 1962, WWF-Indonesia telah memulai penelitian terhadap populasi badak jawa di Ujung Kulon dengan dukungan ahli Dr. Rudolph Schenkel. Saat ini penelitian tentang badak jawa masih terus dilakukan dan diarahkan untuk memperoleh informasi penting tentang pola perilaku, distribusi, migrasi, populasi, sex ratio, dan keragaman genetik.

Selain dari penelitian dan dukungan terhadap patroli anti perburuan badak jawa, WWF Indonesia di 
Taman Nasional Ujung Kulon juga memfokuskan kegiatannya pada upaya manajemen habitat dengan harapan habitat yang terjaga akan dapat mempertahankan populasi yang tersisa dan WWFIndonesia juga menggalang dana untuk konservasi badak jawa dengan mengusung program RhinoCare.

Berdasarkan uraian tersebut, maka peneliti tertarik untuk melakukan penelitian yang dirumuskan dalam judul:

"Peranan World Wide Fund for Nature (WWF) dalam Upaya Konservasi Populasi Badak Jawa Di Indonesia"

Penelitian ini dibuat berdasarkan beberapa matakuliah yang dipelajari peneliti di Program Studi Ilmu Hubungan Internasional, Fakultas Ilmu Sosial dan Ilmu Politik, Universitas Komputer Indonesia. Antara lain sebagai berikut:

1. Pengantar Hubungan Internasional Merupakan peletak dasar bagi penelitian yang akan dilakukan, terkait hubungan para aktor yang melewati batas-batas negara.

2. Organisasi Internasional Didalam matakuliah ini peneliti mempelajari mengenai peran aktor yang terlibat dalam interaksi antar negara yang bersifat internasional dan menciptakan interaksi global didalamnya.

3. Environmental Issues

Pada matakuliah ini membahas tentang masalah-masalah yang terjadi pada lingkungan hidup dan pengaruhnya terhadap global.

\subsection{Rumusan Masalah}

Berdasarkan uraian diatas dan untuk memudahkan dalam menganalisis masalah, peneliti merumuskan masalah sebagai berikut:

"Bagaimana Peranan World Wide Fund for Nature (WWF) dalam Upaya Konservasi Populasi Badak Jawa di Indonesia”. Rumusan Masalah Minor :

1. Apa saja yang dilakukan oleh WWF dalam upaya konservasi populasi badak jawa di Indonesia?

2. Kendala apa yang dihadapi WWF dalam upaya konservasi populasi badak jawa di Indonesia?

3. Rekomendasi apa sajakah yang diberikan oleh WWF untuk pemerintah Indonesia?

\subsection{Maksud dan Tujuan Penelitian}

\subsubsection{Maksud Penelitian}

Penelitian ini dimaksudkan untuk mengetahui peranan WWF sebagai International NonGovernmental Organization (INGO) yang berkonsentrasi dalam konservasi sumber daya alam dalam hal ini konservasi populasi badak jawa di Indonesia.

\subsubsection{Tujuan Penelitian}

Penelitian ini memiliki tujuan, antara lain:

1. Untuk mengetahui, memahami, dan menganalisa upaya yang dilakukan oleh WWF dalam konservasi populasi badak jawa di Indonesia

2. Untuk mengetahui, memahami, dan menganalisa kendala apa saja yang dihadapi WWF dalam upaya konservasi populasi badak Jawa di Indonesia.

3. Untuk mengetahui, memahami, dan menganalisa rekomendasi apa saja yang diberikan WWF untuk pemerintah Indonesia.

\subsection{Kegunaan Penelitian}

Berdasarkan pada tujuan penelitian, maka kegunaan penelitian ini dibagi menjadi dua :

\subsubsection{Kegunaan Teoritis}

Penelitian ini diharapkan dapat berguna untuk memperkaya pengetahuan mengenai keterlibatan suatu Organisasi Internasional, dalam mengatasi suatu permasalahan. Khususnya peranan WWF dalam upaya konservasi populasi badak jawa di Indonesia.

\subsubsection{Kegunaan Praktis}

1. Diharapkan dapat menambah wawasan, ilmu pengetahuan, pengalaman dan kemampuan peneliti di bidang Ilmu Hubungan Internasional.

2. Sebagai bahan referensi bagi penstudi Hubungan Internasional dan umum.

\section{Tinjauan Pustaka dan Kerangka Pemikiran}

\subsection{Tinjauan Pustaka}

Untuk memperoleh pijakan ilmiah dalam penelitian ini, peneliti menggunakan beberapa karya ilmiah yang sudah dibuat sebelumnya dan berkaitan dengan tema yang diangkat dalam skripsi peneliti yakni masalah pelestarian hewan. Salah satu karya ilmiah tersebut adalah skripsi yang berjudul "Kerjasama Indonesia dengan World Wide Fund For Nature (WWF) dalam Menanggulangi Kepunahan Badak di Ujung Kulon" yang dibuat pada tahun 2012 oleh Rasuani Prabu Putra, Universitas Padjajaran. Dalam skripsi tersebut peneliti yang bersangkutan mengangkat masalah yang sama yaitu kepunahan populasi badak jawa di Indonesia. Peneliti yang bersangkutan meneliti bagaimana melalui kerjasama dengan Indonesia, WWF membuat upaya melalui berbagai program yang dirancang bersama 
Indonesia untuk menjaga kelestarian populasi badak di Ujung Kulon. Penelitian ini ditunjukkan untuk menjelaskan upaya-upaya apa saja yang dilakukan oleh WWF sebagai organisasi internasional dalam kerjasamanya dengan Indonesia dalam usaha pelestarian badak jawa. Penelitian ini menghasilkan kesimpulan bahwa kerjasama Indonesia dengan WWF dapat terjalin dengan baik, hal ini terbukti dengan berhasilnya program pelestarian badak jawa dengan meningkatnya populasi badak jawa sebesar $1 \%$ setiap tahunnya.

Karya tulis lain yang membahas permasalahan yang sama adalah sebuah jurnal yang berjudul "Peran World Wide Fund For Nature (WWF) dalam Konservasi Gajah Sumatera di Taman Nasional Tesso Nilo, Riau” yang dibuat tahun 2014 oleh Syarifatul Zannah, Universitas Mulawarman. Dalam karya tulis tersebut penulis yang bersangkutan menjelaskan WWF sebagai organisasi internasional yang bergerak dalam perlindungan atau konservasi keanekaragaman hayati dan sumber daya alam dalam melaksanakan program kerjanya di Taman Nasional Tesso Nilo prihatin dengan isu-isu lingkungan, terutama kepunahan gajah. Berdasarkan situasi ini, WWF Indonesia dan Konservasi Gajah Riau membuat strategi penyelamatan gajah di Taman Nasional Tesso Nilo. Tesso Nilo adalah 86.932 hektar Taman Nasional cadangan untuk gajah sumatera (Elephas maximus sumatranus Temminck) habitat alami. Secara umum, populasi gajah sumatera telah menurun setiap tahun karena habitat yang kurang bagi mereka sebagai perubahan

penggunaan lahan untuk permukiman dan perkembangan non-kehutanan terus berlanjut. Faktor habitat merupakan salah satu aspek yang paling penting dalam manajemen Nation Park. Penelitian ini menghasilkan kesimpulan bahwa WWF telah menjalankan peran dan fungsinya sebagai organisasi internasional, dimana WWF yang bertindak sebagai organisasi internasional yang peduli terhadap sumber daya hayati dan ekosistem khususnya kehidupan gajah sumatera di Taman Nasional Tesso Nilo Provinsi Riau.

Tinjauan pustaka yang lain adalah sebuah karya ilmiah yang berjudul "Upaya World Wide Fund For Nature (WWF) Dalam Mengatasi Perdagangan Ilegal Harimau Sumatera di Provinsi Riau" yang dibuat tahun 2013 oleh Yani Suspina, Universitas Mulawarman. Karya tulis tersebut bertujuan untuk mengetahui bagaimana upaya WWF dalam mengatasi perdagangan ilegal harimau sumatera di Provinsi Riau. Jenis penelitian ini adalah analisis deskriptif dimana penulis menggambarkan dan menjelaskan upaya yang dilakukan oleh WWF dalam meningkatkan upayaupaya untuk mengatasi perdagangan ilegal harimau sumatera. Penelitian tersebut menunjukan bahwa upaya WWF untuk mengatasi perdagangan ilegal harimau sumatera di Provinsi Riau dengan mengadakan pelatihan dan sosialisasi tentang pemberantasan perburuan "Anti Poaching - Illegal Trade Sumatran Tiger" dan proyek perlindungan harimau sumatera di kawasan konservasi.

Dalam karya ilmiah yang lain yang berjudul "Animal Welfare di Jawa Timur: Model Pendidikan Kesejahteraan Binatang di Jawa Timur" yang dibuat tahun 2009 oleh Kellie Joan Eccleston, Universitas Muhammadiyah Malang. Dalam penelitian tersebut membahas kesejahteraan binatang dalam konteks Indonesia. Dalam negara-negara berkembang, seringkali kesejahteraan binatang dilupakan karena belum ada kesejahteraan bagi semua manusia dan kesejahteraan manusia tersebut dianggap sebagai hal yang lebih penting. Oleh karena itu, dengan menginvestigasi bagaimana gerakan kesejahteraan binatang berkembang di Jawa Timur, dalam konteks yang sangat berbeda jika dibandingkan dengan konteks di dunia Barat, dapat meningkatkan pengetahuaan tentang Kesejahteraan Binatang dalam konteks baru. Peneliti ini bertujuan mengevaluasi baik bagaimana masyarakat di Jawa Timur memandang dan memperlakukan binatang maupun tingkat kesadaran dalam masyarakat mengenai Kesejahteraan Binatang. Penelitian ini memfokuskan pada dua lembaga konservasi binatang ProFauna dan Taman Safari Indonesia II. Keduanya merupakan organisasi konservasi binatang yang terkenal di Indonesia dan mempunyai fungsi sebagai pusat pendidikan untuk

Kesejahteraan Binatang. Pendekatan kualitatif digunakan dalam penelitian ini. Hasil kesimpulan dalam penelitian tersebut adalah ada tingkat kesadaran yang cukup memuaskan tentang prinsip-prinsip dasar dalam kesejahteraan binatang di Jawa Timur dan semua responden setuju bahwa masyarakat tidak boleh memperlakukan binatang dengan kejam atau tidak menghiraukannya.

\subsection{Kerangka Pemikiran}

\subsubsection{Hubungan Internasional}

Hubungan Internasional dilaksanakan melalui banyak jalur di samping jalur pemerintah. Sebagai aktor dalam politik global negara juga tidak selalu bertindak sebagai aktor yang unitary dan kelompok- 
kelompok yang ada di dalamnya tidak selalu bertindak secara koheren. Selain negara pun ada banyak aktor lain seperti perusahaan multinasional, organisasi internasional (Jemadu, 2008:46).

Berakhirnya Perang Dingin telah mengakhiri sistem bipolar dan berubah pada multipolar atau secara khusus telah mengalihkan persaingan yang bernuansa militer kearah persaingan atau konflik kepentingan ekonomi di antara negara-negara di dunia. Pasca Perang Dingin, isu-isu Hubungan Internasional yang sebelumnya lebih terfokus pada isu-isu high politics (isu politik dan keamanan) meluas ke isu-isu low politics (isu-isu HAM, ekonomi, lingkungan hidup, dan terorisme) (Perwita \& Yani, 2005:7).

Dalam penelitian ini, penulis mengangkat WWF sebagai aktor dalam hubungan internasional dimana WWF merupakan sebuah organisasi internasional yang melakukan kerjasama dengan pemerintah Indonesia dalam isu lingkungan hidup yaitu kepunahan populasi badak jawa di Indonesia.

\subsubsection{Organisasi Internasional}

Organisasi internasional merupakan salah satu aktor politik internasional. Organisasi internasional diperlukan dalam rangka kerjasama, menyesuaikan dan mencari kompromi untuk meningkatkan kesejahteraan serta memecahkan persoalan bersama, serta mengurangi pertikaian yang timbul. Organisasi juga diperlukan dalam menjajagi sikap bersama dan mengadakan hubungan dengan negara lain. Ciri organisasi internasional yang mencolok ialah merupakan suatu organisasi yang permanen untuk melanjutkan fungsinya yang telah ditetapkan. Organisasi itu mempunyai instrumen dasar (constituent instrument) yang akan memuat prinsip-prinsip dan tujuan, struktur maupun cara organisasi itu bekerja.

Organisasi internasional dibentuk berdasarkan perjanjian, dan biasanya agar dapat melindungi kedaulatan negara, organisasi itu mengadakan kegiatannya sesuai dengan persetujuan atau rekomendasi serta kerjasama, dan bukan semata-mata bahwa kegiatan itu haruslah dipaksakan atau dilaksanakan (Suryokusumo, 2010:10).

Organisasi Internasional merupakan pola kerjasama yang melintasi batas-batas negara dengan didasari struktur organisasi yang jelas dan lengkap serta diharapkan atau diproyeksikan untuk berlangsung dan melaksanakan fungsi-fungsinya secara berkesinambungan dan melembaga guna mengusahakan tercapainya tujuan-tujuan yang diperlukan serta disepakati bersama, baik antara pemerintah dengan pemerintah maupun antara sesama kelompok non-pemerintah pada negara yang berbeda (Rudy, 2009, 93-94). Menurut Clive Archer dalam buku "International Organization", klasifikasi organisasi internasional berdasarkan keanggotaannya terbagi manjadi 2 (dua) macam, yaitu:

1. Type of membership (tipe keanggotaan)

a. International Governmental Organizations (IGO), yaitu organisasi internasional dengan wakil pemerintahan-pemerintahan sebagai anggota.

b. International Non-Governmental Organizations (INGO), yaitu organisasi internasional dimana anggotanya bukan mewakili pemerintahan.

2. Extent of membership (jangkauan keanggotaan)

a. Keanggotaan yang terbatas dalam wilayah tertentu.

b. Keanggotaan yang mencakup seluruh wilayah di dunia (Archer, 2001:66).

Berdasarkan konsep diatas bahwa WWF diartikan sebagai pelaku peranan, dalam hal ini organisasi internasional yang terklasifikasi dalam kategori

INGO's (International Non-Govermental Organization) yang kemudian didalamnya terdapat mekanisme kerja dan fungsinya tersendiri yang dijalankan untuk memenuhi visi misi dari WWF itu sendiri.

\subsubsection{International Non-Governmental Organization (INGO)}

Bentuk INGO mulai dikenal pada tahun 1846. Yang tercatat sebagai INGO pertama, dalam berbagai literatur, adalah World's Evangelical Alliance

(Perhimpungan Penginjil Sedunia). Kemudian menyusul terbentuknya beberapa INGO lainnya, sejak pertengahan abad ke XIX (sekitar tahun 1860). Berjalan seiring dengan berkembanganya kerjasama internasional dalam bentuk organisasi-organisasi internasional antarpemerintah (IGO). Setelah PD I dan PD II maka banyak INGO terbentuk, seperti juga halnya IGO yang makin digandrungi pada masa itu. Untuk bentuk kerjasama IGO, perkembangan pesat terjadi antara tahun1921 sampai tahun 1930, dan antara tahun 1941 sampai 1960.

\subsection{Definisi INGO}

Definisi “internasional NGO” (INGO) pertama kali diberikan dalam resolusi 288 (X) ECOSOC pada 27 Pebruari 1950 bahwa setiap organisasi internasional tidak didirikan atas dasar sebuah perjanjian internasional. World Bank, medefinisikan NGO sebagai organisasi swasta yang menjalankan kegiatan untuk meringankan penderitaan, mengentaskan kemiskinan, memelihara lingkungan hidup, menyediakan layanan sosial dasar atau 
melakukan kegiatan pengembangan masyarakat. Dalam sebuah dokumen penting Wold Bank, Working With $N G O s$, disebutkan, dalam konteks yang lebih luas, istilah NGO dapat diartikan sebagai semua organisasi nirlaba (non-profit organization) yang tidak terkait dengan pemerintah (Suparni, 1994:17).

\subsection{Jenis-Jenis Non-}

\section{Governmental Organization (NGO)}

Dalam dokumen World Bank (1989), cenderung untuk membedakan antara dua kategori utama dalam NGO, yaitu NGO operasional dan NGO advokasi.

Fungsi operasional dari sebuah NGO terkait dengan merancang dan melaksanakan program aksi konkret yang secara langsung menghasilkan perubahan kondisi orang, artefak budaya, atau lingkungan alam seperti pengembangan, bantuan pangan, perawatan

kesehatan, perlindungan bangunan bersejarah, perlindungan kesejahteraan hewan, konservasi alam dll. Fungsi advokasi dari NGO bertujuan untuk mempengaruhi pendapat, kebijakan, dan praktik otoritas nasional dan internasional pemerintah, badan usaha, kelompok sosial, dan masyarakat umum. Meskipun mereka tidak langsung berorientasi pada perubahan kondisi nyata realitas, mereka melakukannya dengan mempengaruhi perantara (Vedder, 2007:5).

\subsection{Kekuatan dan Kelemahan NGO}

World Bank telah menilai kekuatan dan kelemahan NGO, tetapi mengakui bahwa sifat dan kualitas NGO individu sangat bervariasi. Meskipun keragaman ini, mereka menarik kesimpulan sebagai berikut : A. Kekuatan NGO:

1. Link akar rumput yang kuat

2. Keahlian pengembangan berbasis lapangan

3. Kemampuan untuk berinovasi dan beradaptasi

4. Pendekatan proses yang berorientasi pada pembangunan

5. Metodologi partisipatif dan alat

6. Komitmen jangka panjang dan penekanan pada keberlanjutan

7. Efektivitas biaya

B. Kelemahan NGO:

1. Terbatas keahlian keuangan dan manajemen

2. Terbatas kapasitas kelembagaan

3. Rendahnya tingkat kemandirian

4. Isolasi / kurangnya komunikasi antar - organisasi dan / atau koordinasi
5. Intervensi skala kecil

6. Kurangnya pemahaman tentang konteks sosial atau ekonomi yang lebih luas (Cernea, 1988:1719).

\subsubsection{Peranan Organisasi Internasional}

Menurut Leroy Bennet dalam buku International Organization, Principle and Issue, sejajar dengan negara, organisasi internasional dapat melakukan dan memiliki sejumlah peranan penting, yaitu:

1. Menyediakan sarana kerjasama diantara negaranegara dalam berbagai bidang, dimana kerjasama tersebut memberikan keuntungan bagi sebagian besar ataupun keseluruhan anggotanya. Selain sebagai tempat dimana keputusan tentang kerjasama dibuat juga menyediakan perangkat administratif untuk menerjemahkan keputusan tersebut menjadi tindakan.

2. Menyediakan berbagai jalur komunikasi antar pemerintah negara-negara, sehingga dapat dieksplorasi dan akan mempermudah aksesnya apabila timbul masalah (Bennet, 2002:3).

Peranan organisasi internasional dapat digambarkan sebagai individu yang berada dalam lingkungan masyarakat internasional. Sebagai anggota masyarakat internasional, organisasi internasional harus tunduk pada peraturan-peraturan yang telah disepakati bersama. Selain itu, melalui tindakan anggotannya, setiap anggota tersebut melakukan kegiatan-kegiatan dalam rangka mencapai tujuannya.

Organisasi internasional sangat berperan sebagai aktor hubungan internasional karena organisasi internasional sebagai wadah atau instrument bagi koalisi antar anggota atau koordinasi kebijakan antar pemerintah, seperti bagaimana WWF berperan dalam mengurangi kepunahan populasi badak Jawa di Indonesia.

\subsubsection{Kerjasama Internasional}

Kerjasama internasional merupakan suatu perwujudan kondisi masyarakat yang saling tergantung satu dengan yang lain. Dalam melakukan kerjasama ini dibutuhkan suatu wadah yang dapat memperlancar kegiatan kerjasama tersebut. tujuan dari kerjasama ini ditentukan oleh persamaan kepentingan dari masingmasing pihak yang terlibat. Kerjasama internasional dapat terbentuk karena kehidupan internasional meliputi bidang, seperti ideologi, politik, ekonomi, 
sosial, lingkungan hidup, kebudayaan, pertahanan dan keamanan (Perwita dan Yani, 2005: 34).

Dalam suatu kerjasama internasional bertemu berbagai macam kepentingan nasional dari berbagai negara dan bangsa yang tidak dapat dipenuhi di dalam negerinya sendiri (Perwita dan Yani, 2005; 33). Seperti yang dilakukan organisasi WWF dengan Pemerintah Indonesia, kerjasama yang di jalin adalah untuk membantu pemerintah Indonesia dalam mengurangi kepunahan populasi badak jawa di Indonesia.

\subsubsection{Isu Lingkungan dalam Hubungan Internasional}

Isu lingkungan hidup menjadi perbincangan hangat di kancah dunia internasional pasca terjadinya perang dingin. Beberapa negara mulai menyadari pentingnya lingkungan untuk kelangsungan hidup bagi generasi di masa yang akan datang. Dengan meningkatnya kesadaran lingkungan masyarakat dunia umumnya dan kalangan pemerintahan ditingkat negarabangsa khususnya dan bertambahnya persoalan kemerosotan lingkungan hidup yang sudah menyentuh kehidupan kita sehari-hari, seperti memanasnya suhu bumi dan meningkatnya jenis dan kualitas penyakit akibat berlubangnya lapisan ozon, maka isu lingkungan hidup diangkat dalam agenda percaturan internasional (Rudy, 2011:58).

\subsubsection{Sejarah Perkembangan Isu Lingkungan}

Isu lingkungan hidup pertama kali diangkat sebagai sebagai salah satu agenda dalam pertemuan negara-negara dalam ranah hubungan internasional pada tahun 1970-an, hal ini ditandai dengan diselenggarakannya Konferensi Perserikatan BangsaBangsa (PBB) tentang lingkungan hidup pada tahun 1972 di Stockholm, Swedia yang lebih dikenal dengan Stockholm Conference. Sejak tahun ini isu lingkungan hidup dan pembangunan menjadi agenda penting di forum regional dan multilateral hal ini dikukuhkan dengan diadakannya beberapa pelaksanaan konferensi internasional antara lain: pertama, Mengenai "Human Environment" di Stocholen Swedia. Konferensi kedua dalam sidang majelis umum PBB ke-27 membentuk "Governing Council United Nations Environment Program (GC-UNEP) yang memberi mandat antara lain:

1. Mendorong kerjasama internasional di lingkungan hidup

2. Menerbitkan laporan mengenai kondisi lingkungan global termasuk mengkaji dampak penerapan dampak kebijakan dalam lingkungan bagi kegiatan-kegiatan pembangunan di negara berkembang.

Konferensi lingkungan hidup PBB yang berlangsung di Stockholm tersebut kemudian menghasilkan sebuah resolusi mengenai pembentukan United Nations
Environmental Program (UNEP), dapat dikatakan bahwa UNEP merupakan awal pelaksana komitmen mengenai lingkungan hidup dalam hubungan kerjasama antar negara, yang kemudian melahirkan gagasan dari pembangunan berkelanjutan (Sustainable Development) dengan pertemuan-pertemuan serta pembahasan yang berkesinambungan, dan diangkat secara global dalam forum dan konferensi internasional. Dalam perkembangannya konferensikonferensi internasional yang membahas mengenai masalah lingkungan dari tahun ketahun seperti yang tertera diatas, terus diadakan dalam mencari solusi dalam penanggulangan masalah yang dianggap sulit dalam tata lingkungan hidup global saat ini, pertemuan antar negara-negara dalam membahas masalah lingkungan hidup terangkum dalam UNFCCC (United Nations Framework Convention on Climate Change), dimana hasil dari salah satu pertemuan UNFCCC yang diadakan yaitu mengenai kesepakatan negara-negara pada tahun 1997 untuk membuat konsensus penanganan lingkungan yang dirangkum dalam suatu protokol yang disebut Protocol Kyoto, hingga dalam perkembangan berikutnya pertemuan lingkungan yang melibatkan negara-negara masih terus dilakukan dalam lingkup UNFCCC.

\subsubsection{Global Environmental Politics}

Politik lingkungan hidup, menurut Walters, mempelajari bagaimana manusia mengorganisasikan dirinya dan struktur perilakunya untuk melindungi kepentingan mereka di dalam lingkungan. Ia mempelajari dinamika gerakan-gerakan sosial, kelembagaan dan pembuatan kebijakan pemerintah serta interaksi yang terjadi di dalamnya. Sebagai subjek akademik, politik lingkungan hidup termasuk cabang kajian baru dan interdisiplin yang dipengaruhi oleh ilmu sejarah, ilmu politik, geografi, sosiologi, antropologi dan ilmu lingkungan (Walters, 2004:1).

Setelah tiga dekade dari permulaan kajian politik lingkungan hidup ini, Dauvergne (2005:21) melihat bahwa nampaknya kajian politik lingkungan hidup ke depan akan melampaui bidang ilmu politik (termasuk ilmu hubungan internasional dan hukum internasional) itu sendiri. Hal ini dilihat dari isu-isu yang saat ini terus berkembang seperti pemanasan global, perubahan iklim, keanekaragaman hayati, air bersih, deforestasi dan lain sebagainya yang menuntut sebuah bentuk penelitian yang multidisiplin.

Dalam penelitian ini, fenomena kepunahan populasi badak jawa merupakan salah satu dari kajian politik lingkungan hidup yang berkembang saat ini. Penelitian ini menganalisa peran WWF sebagai sebuah organisasi internasional dalam mengatasi fenomena tersebut. 


\subsubsection{Konvensi Internasional untuk} Menyelamatkan Lingkungan Hidup

Masalah-masalah lingkungan hidup dapat menjadi bencana yang dapat mempengaruhi kualitas hidup manusia. Tanda-tanda masalah lingkungan hidup seperti adanya polusi, global warming, fotokimia kabut, hujan asam, erosi, banjir, instrusi dan lain sebagainya sudah mulai terlihat sejak pertengahan abad ke -20. Hal ini yang menjadi dasar munculnya konvensi-konvensi untuk menyelamatkan lingkungan hidup, seperti :

1. International Whaling Commission (IWC)

2. The International Convention for the Prevention of Pollution from Ships/Marine Pollution (MARPOL)

3. United Nations Convention on the Law of the Sea (UNCLOS)

4. Vienna Convention on Substances That Deplete the Ozone Layer

5. Montreal Protocol

6. Basel Convention

7. United Nations Framework Convention on Climate Change (UNFCCC)

8. Kyoto Protocol

9. United Nations Convention to Combat Desertification (UNCCD)

10. Stockholm Convention (O'Neill, 2009:73-75)

\subsubsection{Konvensi Internasional tentang Perlindungan Hewan \\ 2.2.5.1.1 Convention on Biological Diversity (CBD)} Konvensi Keanekaragaman Hayati terinspirasi oleh komitmen tumbuh masyarakat dunia terhadap pembangunan berkelanjutan. Ini merupakan langkah maju yang dramatis dalam konservasi keanekaragaman hayati, pemanfaatan secara berkelanjutan komponenkomponennya, dan pembagian yang adil dan merata dari keuntungan yang diperoleh dari pemanfaatan sumber daya genetik.

\subsection{Cartagena Protocol on Biosafety}

Protokol berusaha untuk melindungi keanekaragaman hayati dari potensi risiko yang ditimbulkan oleh organisme hasil modifikasi yang dihasilkan dari bioteknologi modern. Protokol ini menetapkan suatu kemajuan persetujuan berdasarkan informasi prosedur untuk memastikan bahwa negara-negara harus dilengkapi dengan informasi yang diperlukan untuk membuat keputusan sebelum menyetujui impor organisme tersebut ke wilayah mereka. Protokol berisi referensi ke pendekatan pencegahan dan menegaskan kembali langkah pencegahan dalam Prinsip 15 Deklarasi Rio tentang Lingkungan dan Pembangunan. Protokol ini juga menetapkan Biosafety ClearingHouse untuk memfasilitasi pertukaran informasi tentang organisme hasil modifikasi dan untuk membantu negara-negara dalam pelaksanaan protokol ini.

\subsection{World Heritage Convention}

Fitur yang paling signifikan dari 1972 Konvensi Warisan Dunia adalah bahwa ia menghubungkan bersama-sama dalam satu dokumen konsep konservasi alam dan pelestarian kekayaan budaya. Konvensi ini mengakui cara di mana orang berinteraksi dengan alam, dan kebutuhan mendasar untuk menjaga keseimbangan antara keduanya.

Konvensi menetapkan tugas dari negaranegara pihak dalam mengidentifikasi lokasi potensial dan peran mereka dalam melindungi dan melestarikan mereka. Dengan menandatangani konvensi, masingmasing negara berjanji untuk melestarikan tidak hanya situs Warisan Dunia terletak di wilayahnya, tetapi juga untuk melindungi warisan nasional. Negara-negara pihak didorong untuk mengintegrasikan perlindungan warisan budaya dan alam ke dalam program perencanaan daerah, mengatur staf dan layanan di situs mereka, melakukan penelitian konservasi ilmiah dan teknis dan mengadopsi langkah-langkah yang memberikan warisan ini fungsi dalam kehidupan sehari-hari masyarakat. Ini menjelaskan bagaimana Heritage Fund yang akan digunakan dan dikelola dan dalam kondisi apa bantuan keuangan internasional dapat diberikan.

\subsection{Convention on Migratory Species}

Konvensi tentang Konservasi Spesies Satwa Liar Bermigrasi (juga dikenal sebagai CMS atau Bonn Convention) bertujuan untuk melestarikan spesies yang bermigrasi darat, air dan burung di seluruh jangkauan mereka . Ini adalah perjanjian antar pemerintah, menyimpulkan bawah naungan United Nations Environment Programme (UNEP), berkaitan dengan konservasi satwa liar dan habitat dalam skala global. Sejak masuknya Konvensi berlaku pada tanggal 1 November 1983, keanggotaannya telah berkembang untuk memasukkan 119 Pihak (per 1 April 2013) dari Afrika, Amerika Tengah dan Selatan, Asia, Eropa, dan Oceania.

\subsection{Convention on International Trade in Endangered of Wild Flora and Fauna (CITES) \\ Convention on International Trade in} Endangered Species of wild Fauna and Flora (CITES) adalah suatu perjanjian multilateral untuk menjawab salah satu faktor ancaman dari kepunahan spesies. CITES terbentuk pada tahun 1973 dan mulai berlaku 1975. Karena kegiatan perdagangan satwa liar ini melintasi batas negara atau paling tidak melibatkan dua negara, usaha untuk membuat perjanjian internasional adalah jalan terbaik dengan terbentuknya CITES untuk melindungi spesies tertentu dari eksploitasi yang berlebihan (Hutton \& Graham, 2000: 5).

Didalam CITES mekanisme pengendalian perdagangan satwa yang digunakan adalah dengan 
menggunakan mekanisme regulasi apendiks. Ada 3 macam Apendik:

1. Apendik I merupakan yang tertinggi dimana spesies tersebut terancam punah dan perdagangan spesies hanya diinginkan dalam kondisi tertentu.

2. Apendiks II adalah spesies yang tidak terancam punah tetapi akan mengalami kepunahan apabila tidak dikontrol dan dimonitor secara ketat

3. Apendiks III adalah kategori spesies yang dimasukkan dalam daftar oleh negara-negara anggota CITES dimana, suatu negara merasa suatu spesies tertentu sedang atau harus dilindungi di bawah hukum nasionalnya dan perlu adanya kerjasama lebih lanjut dengan sesama negara anggota CITES untuk mengontrol perdagangan internasional terhadap spesies tersebut.

\subsubsection{Konsep Konservasi Lingkungan}

Konservasi berasal dari kata "Conservation" yang terdiri atas kata con yang berarti together dan servare yang berarti "keep/save" yang memiliki pengertian upaya memelihara apa yang kita punya, namun secara bijaksana/wise use. Konsep ini pertama kali dikemukakan oleh Theodore Roosevelt (1902) yang merupakan orang Amerika pertama yang mengemukakan tentang konsep konservasi.

Apabila merujuk pada pengertiannya, konservasi didefinisikan dalam beberapa batasan, sebagai berikut :

1. Berdasarkan American Dictionary, konservasi adalah menggunakan sumberdaya alam untuk memenuhi keperluan manusia dalam jumlah yang besar dalam waktu yang lama.

2. Menurut Randall (1982), Konservasi adalah alokasi sumberdaya alam antar waktu (generasi) yang optimal secara sosial.

3. MenurutIUCN (1968), Konservasi merupakan manajemen udara, air, tanah, mineral ke organisme hidup termasuk manusia sehingga dapat dicapai kualitas kehidupan manusia yang meningkat termasuk dalam kegiatan manajemen adalah survai,

penelitian, administrasi, preservasi, pendidikan, pemanfaatan dan latihan.

4. Menurut Wildlife Conservation Society (WCS) (1980), Konservasi adalah manajemen penggunaan biosfer oleh manusia sehingga dapat memberikan atau memenuhi keuntungan yang besar dan dapat diperbaharui untuk generasi-generasi yang akan datang.

\section{Objek dan Metode Penelitian 3.1 Tinjauan Umum World Wide Fund for Nature} (WWF)
WWF adalah yayasan yang independen, tidak memihak dan obyektif dalam berurusan dengan pemerintah, partai politik, organisasi dan individu lain. Tujuan didirikannya organisasi ini yaitu untuk melestarikan lingkungan alam dan proses ekologi di seluruh dunia. Hal ini diambil untuk memasukkan fauna dan flora, landscape, air, tanah, udara dan sumber daya alam lainnya, dengan penekanan khusus pada pemeliharaan proses ekologi esensial dan sistem pendukung kehidupan, dan pada pelestarian genetik, spesies dan ekosistem, dan untuk memastikan bahwa pemanfaatan spesies liar dan ekosistem alami yang berkelanjutan, dan khususnya:

a. Untuk mengumpulkan, mengelola dan menyalurkan dana untuk konservasi alam, untuk meninjau kebutuhan jangka panjang konservasi di seluruh dunia dan untuk mempelajari dan mengembangkan cara memenuhi persyaratan ini .

b. Untuk meningkatkan kesadaran akan perlunya konservasi alam dan membantu dalam merancang, memproduksi dan membuat bahan yang cocok yang tersedia untuk tujuan pendidikan, kampanye, pameran dan media untuk membantu pertumbuhan dan perkembangan gerakan konservasi di seluruh dunia.

c. Untuk membiayai kegiatan konservasi dan proyek-proyek termasuk penelitian dan

pertukaran ilmuwan, spesialis dalam konservasi alam, mahasiswa dan lain-lain, terutama dari negara-negara berkembang, dan untuk mempromosikan dan berpartisipasi

dalam konferensi, seminar, ceramah, pertemuan dan diskusi sebagai kelanjutan konservasi alam di seluruh dunia

d. Untuk melindungi, memperoleh, mengelola, mengeksploitasi secara komersial dan membuang tanah dan properti lainnya dan sumber daya, termasuk kekayaan intelektual.

e. Mengembangkan dukungan moral dan keuangan di seluruh dunia untuk konservasi alam dan menunjuk wakil dan membangun afiliasi, terkait atau organisasi anak dalam setiap bagian dari dunia dan untuk bekerja sama dengan, dan dukungan, organisasiorganisasi lain di bidang konservasi, dan terlibat dalam keuangan, komersial dan kegiatan kondusif lainnya.

f. Untuk mencapai misi sebagaimana yang ditetapkan dari waktu ke waktu oleh Dewan Internasional sesuai dengan tujuan di atas.

\subsubsection{Sejarah Lahir dan Perkembangan WWF}

Berdirinya WWF (waktu itu masih World Wildlife Fund) bermula dari pemikiran energik seorang pakar 
biologi berkebangsaan Inggris, Sir Julian Huxley. Huxley saat itu menjabat sebagai Direktur Jenderal pertama badan milik PBB, UNESCO. Selama dalam di UNESCO, Huxley acapkali melakukan perjalanan ke negara-negara baru merdeka di benua Afrika. Hasil dari perjalanan ilmiahnya itu, Huxley mendapat masukan yang berarti, khususnya dalam hal pelestarian hidupan liar di sana. Dari hasil pengamatannya tersebut, Huxley berupaya menggugah kesadaran masyarakat Inggris saat itu melalui berbagai tulisannya di media massa. Tujuannya, agar masyarakat Inggris menghentikan kebiasaan berburu binatang di Afrika, karena binatang tersebut terancam punah. Dari tulisan itu kemudian banyak respon yang diterima oleh Huxley. Salah satunya seorang pengusaha, Victor Stolan, menanggapi dan menekankan perlunya dibentuk organisasi internasional, yang mengurusi pelestarian alam. Dari rangkaian dialog Huxley dengan Stolan, kemudian Huxley menghubungi rekannya, Direktur Jenderal Pelestarian Alam Inggris, Max Nicholson. Pembicaraan pun berkembang. Nicholson lalu mengundang sejumlah pakar dari berbagai disiplin ilmu, untuk mendirikan organisasi internasional yang menangani pelestarian alam.

Tepatnya pada 11 September 1961, WWF berdiri, di mana Peter Scott menjadi ketuanya yang pertama. Scott saat itu juga menjabat sebagai Wakil Presiden International Union for Conservation of Nature (IUCN). Negara yang dipilih menjadi markas adalah Swiss, karena sudah terkenal dengan sikap kenetralannya. Pada saat bersamaan, tiba seekor beruang Panda bernama Chi-Chi di kebun binatang London. Momentum itu kemudian mengangkat binatang berbulu tebal, dengan titik hitam di sekitar matanya, sebagai simbol organisasi. Sejak itu, WWF Internasional memulai debutnya secara global, dengan membuka jaringan lintas benua dan negara, serta mengeluarkan berbagai imbauan nasional yang menekankan pentingnya pelestarian alam. Dana akhirnya berdatangan, sebagai wujud simpati masyarakat dunia terhadap kiprah WWF. Organisasi ini pernah dipimpin Pangeran Bernhard dari Negeri Belanda dan Pangeran Phillips dari Kerajaan Inggris.

Pada era 1980-an, WWF memperluas jaringan kerja dengan berbagai organisasi serupa bertaraf internasional, misalnya, dengan badan-badan PBB. Strategi ini memungkinkan penyebarluasan kepedulian secara global dan holistik. WWF Internasional lalu mengubah nama organisasi, agar lebih pas dengan perluasan aktivitasnya, yakni dari World Wildlife Fund menjadi World Wide Fund For Nature. Saat ini WWF adalah organisasi pelestarian lingkungan independen terbesar di dunia. WWF memiliki 4,7 juta pendukung dan sebuah jaringan global yang terdiri dari 27 organisasi nasional, 22 kantor program, dan lima organisasi afiliasi.

\subsubsection{Visi, Misi dan Strategi}

WWF sebagai organisasi internasional yang peduli terhadap lingkungan hidup mempunyai misi yaitu untuk melestarikan alam dan mengurangi ancaman yang paling mendesak untuk keanekaragaman kehidupan di Bumi. Sedangkan visi WWF adalah untuk membangun masa depan di mana orang hidup dalam harmoni dengan alam .

WWF berusaha untuk menyelamatkan planet, sebuah dunia kehidupan. Mendamaikan kebutuhan manusia dan kebutuhan orang lain yang berbagi bumi, WWF berusaha untuk menjalankan konservasi yang manusiawi dalam arti yang luas. Dari komunitas terkecil kepada organisasi multinasional terbesar, WWF berusaha untuk menginspirasi orang lain yang bisa memajukan konservasi.

\subsubsection{Sumber Dana Operasional WWF}

WWF membutuhkan dana untuk menjalankan aktivitasnya dimana dana tersebut bersumber pada individu, sumber-sumber pemerintah dan dari perusahaan dan lain-lain. Penyumbang dana terbesar WWF berasal dari Eropa dan Amerika Serikat yang disebut dengan negara-negara fundraiser, mereka melakukan penggalangan dana melalui kampanye dan dana yang di peroleh kebanyakan berasal dari individu, contohnya dari WWF Belanda yang mendapat suntikan dana dari sebagian besar indivudial masyarakat yang memberikan bantuan langsung baik dalam bentuk materi juga kepada WWF.

Seperti pada tahun 2010 sumber dana WWF 57\% berasal dari dana dari individu dan warisan, $17 \%$ dari sumber-sumber pemerintah (seperti Bank Dunia, DFID, USAID) dan $11 \%$ dari perusahaan.

\subsubsection{Struktur WWF Internasional}

WWF Indonesia merupakan bagian independen dari jaringan WWF Internasional dan afiliasinya, organisasi pelestarian global yang bekerja di 100 negara di dunia untuk mencapai mimpi pelestarian yaitu mewujudkan dunia dimana manusia dapat hidup selaras dengan alam. Struktur WWF Internasional dibagi menjadi 3 jenis organisasi di bawahnya, yaitu:

1. Project Office WWF

2. Programme Office WWF

Kedua jenis organisasi ini hanya menjadi eksekutor dari program-program kerja yang disusun oleh WWF Global di negara tempat kantor tersebut didirikan.

3. National Office WWF

National Office ini sudah memiliki organisasi sendiri dan base-nya adalah lokal. Setiap National Office berhak menetapkan kebijakan dan program untuk organisasinya, namun tetap menggunakan logo dan afiliasi WWF dengan membayar alokasi tertentu dari selisih pemasukan yang diterima dan 
pengeluaran yang dilakukan oleh National Office kepada WWF Global Pusat.

\subsubsection{WWF-Indonesia}

\subsubsection{Latar Belakang Hadirnya WWF di Indonesia}

Pada tahun 1962 WWF Internasional membuka kantor program di Indonesia, kurang dari setahun setelah WWF Internasional didirikan. Selama lebih dari 33 tahun, WWF-Indonesia telah bekerjasama dengan badan-badan pemerintah, organisasi-organisasi non- pemerintah, universitas dan para pemuka masyarakat, untuk mempromosikan pembangunan berkelanjutan dan pelestarian alam di Indonesia. Ini punya arti penting karena Indonesia adalah wilayah yang secara hayati paling beraneka-ragam di dunia.

Mengenal WWF-Indonesia dan karyanya di sepanjang kepulauan Indonesia, merupakan salah satu negara dengan wilayah pesisir dan keanekaragaman hayati terkaya di dunia. Ironisnya mayoritas penduduk Indonesia hidup dalam kemiskinan, kota-kotanya merupakan tempat paling tercemar di dunia. Setiap tahun, hijaunya hutan berubah menjadi merah menyala karena terbakar, dan ketika musim penghujan tiba, bencana banjir serta longsor membawa petaka bagi banyak orang. Tujuan utama WWF-Indonesia adalah untuk menghentikan dan memperbaiki kerusakan lingkungan yang terjadi serta membangun masa depan, dimana manusia hidup selaras dengan alam.

Pada Juli 1998, WWF Indonesia Program mengubah statusnya dari Kantor Program (Program Office) menjadi Organisasi Nasional (National Organization) berbadan hukum Yayasan dan masuk ke dalam jaringan WWF Internasional ke-27. Perubahan status ini merupakan bagian dari rencana strategis, untuk memenuhi tuntutan-tuntutan yang lebih besar yang diharapkan dari organisasi. Perubahan status diharapkan akan memungkinkan WWF-Indonesia memperluas cakupan bidang kerja dan kemampuannya, dan menyelenggarakan pengumpulan dana terpisah dari markas besar WWF Internasional di Gland, Swiss. Perubahan status WWF-Indonesia juga diiringi kemudian dengan perubahan jajaran pengurusnya. Sebelumnya, WWF-Indonesia sebagai organisasi yang masih berstatus Kantor Program dari WWF Internasional dikelola oleh warga non-Indonesia.

\subsubsection{Kerjasama dengan Pemerintah Indonesia WWF-Indonesia merupakan bagian dari}

WWF Internasional dan masuk ke dalam jaringan WWF Internasional ke-27. Hal ini mendorong WWFIndonesia melakukan kerjasama dengam pemerintah Indonesia dalam upaya menjaga lingkungan hidup di wilayah Indonesia. Seperti kerjasama yang dilakukan WWF-Indonesia dengan Kementerian Kelautan dan Perikanan (KKP) untuk perikanan berkelanjutan, kedua lembaga tersebut menandatangani sebuah Nota Kesepahaman Kerjasama (NKK/MoU) di Kantor KKP,
Jakarta Pusat. Kerjasama lainnya dilakukan antara WWF Indonesia dengan Pemerintah Provinsi Nusa Tenggara Barat (NTB) dengan menyepakati perjanjian kerja sama pengelolaan Sumber Daya Alam dan lingkungan hidup. Perjanjian kerja sama dalam kurun waktu tiga tahun (2011-2014) itu merupakan kelanjutan dari perjanjian periode tiga tahun sebelumnya yakni 2009-2011.

Kerjasama juga dilakukan WWF-Indonesia dengan Pemerintah Kabupaten (Pemkab) Malinau, Kalimantan Utara, dengan menandatangani Nota Kesepahaman kerjasama yang menjadi langkah awal persiapan penyelenggaraan konsep pembangunan hijau di Kabupaten Malinau selama 5 tahun yang akan datang (2014-2019).

\subsubsection{Program WWF di Indonesia}

Dalam hal program konservasi, programprogram dikembangkan sesuai dengan tema atau isu strategis. Isu straregis yang yang dikembangkan WWF Indonesia mempunyai kesamaan dengan isi-isu di seluruh WWF Global Network.

1. Program Iklim dan Energi

2. Program Kehutanan-Spesies

3. Program Kelautan

\subsection{Program WWF untuk Spesies}

WWF-Indonesia memfokuskan kerjanya dalam sejumlah spesies prioritas yang memiliki signifikansi khusus pada lingkungannya, yang dinilai berdasarkan aspek-aspek berikut: signifikansi spesies tersebut pada ekosistem, statusnya sebagai komponen penting pada rantai makanan, kontribusinya pada stabilitias atau regenerasi habitat, nilai pentingnya pada kemakmuran masyarakat lokal, serta spesies yang memiliki peranan sebagai ikon budaya.

Dengan secara strategis memfokuskan upaya konservasi pada spesies ini akan secara langsung membantu konservasi spesies penting lainnya yang hidup di habitat yang sama dan menghadapi ancaman yang sama bagi kelestariannya. Spesies-spesies tersebut antara lain:

1. Harimau Sumatera

WWF-Indonesia bekerja sama dengan pemerintah Indonesia, organisasi konservasi lainnya, dan masyarakat setempat untuk menyelamatkan harimau Sumatera dari ancaman kepunahan. WWF-Indonesia juga berupaya melakukan pendekatan dan bekerja sama dengan perusahaan yang konsesinya mengancam habitat harimau agar mereka

mampu menerapkan praktik-praktik pengelolaan lahan yang lebih baik (Better Management Practices) dan berkelanjutan. Pemerintah Indonesia di tahun 2004 telah mendeklarasikan sebuah kawasan penting, Tesso Nilo, sebagai taman nasional untuk memastikan perlindungan gajah dan harimau 
Sumatera di alam. WWF-Indonesia juga berpartisipasi aktif dalam penyusunan Strategi dan Rencana Aksi Konservasi Harimau Sumatera 2007-2017 yang dipimpin oleh Departemen Kehutanan RI.

2. Orangutan Sumatera

WWF-Indonesia membantu Kementerian Negara Lingkungan Hidup, Departemen Pekerjaan Umum dan Departemen Kehutanan dalam mengembangkan Rencana Tata Ruang Berbasiskan Ekosistem Pulau Sumatera, sebagai upaya penyelamatan sebagai restorasi hutan tersisa di Sumatera. WWF-Indonesia juga bekerjasama dengan berbagai pihak untuk melindungi lansekap hutan yang tersisa di Bukit Tiga Puluh dan Jambi di mana lansekap tersebut juga merupakan areal introduksi orangutan Sumatera di alam. WWF-Indonesia juga bekerja bersama sejumlah LSM yang bergerak di bidang pelestarian orangutan dalam mempublikasikan panduan teknis Penanganan Konflik Manusia dan Orangutan di Dalam dan Sekitar Perkebunan Kelapa Sawit. Dokumen tersebut dimaksudkan untuk membantu sektor industri dalam mengidentifikasi dan menentukan langkahlangkah yang tepat untuk mengadopsi praktikpraktik pengelolaan yang lebih baik (Beter Management Practices/BMP) yang bermanfaat bagi konservasi dan industri. WWF-Indonesia juga terlibat secara aktif dalam pengembangan Rencana Aksi dan Strategi Konservasi Orangutan yang dirilis oleh Presiden RI tahun 2007.

3. Gajah Sumatera

WWF-Indonesia bekerja di tiga wilayah di Sumatera yang dinilai sangat penting bagi upaya konservasi gajah. Terobosan-terobosan besar telah berhasil dicapai dengan dideklarasikannya Taman Nasional Tesso Nilo di Riau (tahap I seluas 38,576 ha) oleh Departemen Kehutanan pada tahun 2004. Pada tahun 2006, Menteri Kehutanan menetapkan Provinsi Riau sebagai Pusat Konservasi Gajah Sumatera melalui Permenhut No. 5/2006. Hal ini merupakan langkah besar bagi penyelamatan habitat gajah di Sumatera.

Pada tahun 2004, WWF-Indonesia memperkenalkan Tim Patroli Gajah Flying Squad pertama di Desa Lubuk Kembang Bunga yang berada di sekitar Taman Nasional Tesso Nilo yang baru ditetapkan. Tim ini, yang terdiri dari sembilan pawang dan empat gajah latih, mengarahkan gajah-gajah liar untuk kembali ke hutan apabila mereka memasuki ladang maupun kebun milik masyarakat desa tersebut.

4. Orangutan Kalimantan
WWF-Indonesia bekerjasama dengan berbagai pihak seperti pemerintah Indonesia, organisasi dan masyarakat lokal, untuk menyelamatkan dan mengurangi kerusakan habitat orangutan. Tiga komponen WWF-Indonesia dalam melaksanakan kegiatan konservasi orangutan di Heart of Borneo adalah:

1. Memfasilitasi terciptanya sebuah jaringan dari kawasan-kawasan lindung sebagai sebuah kawasan perlindungan untuk spesies kunci, seperti orangutan. Menghubungkan kawasan-kawasan lindung tersebut dengan 'koridor satwa' yang dikelola secara teliti, memastikan orangutan dan spesies lain dapat bergerak dengan leluasa di dalamnya.

2. Memastikan semua kawasan lain di dalam maupun di perbatasan Heart of Borneo yang statusnya tidak dilindungi dapat dipertahankan sama seperti kawasan hutan dengan cara dikelola secara berkelanjutan. Lebih dari $70 \%$ populasi orangutan Borneo diperkirakan berada di luar kawasan-kawasan yang dilindungi, dengan mayoritas berada di dalam kawasan konsesi. Penelitian WWFIndonesia menunjukkan bahwa orangutan Borneo mampu bertahan hidup di kawasan hutan konsensi, apabila dampak penebangan dikurangi melalui implementasi Pengelolaan Hutan Berkelanjutan, penebangan dilakukan secara selektif, keutuhan pohon-pohon berbuah tetap dijaga, serta aktivitas perburuan dikontrol secara ketat.

3. Melalukan kampanye penyadartahuan tentang konservasi orangutan kepada kelompok-kelompok masyarakat, terutama masyarakat lokal yang tinggal berbatasan dengan habitat orangutan.

\subsection{Kondisi Populasi Badak Jawa di Indonesia}

Badak ini pernah menjadi salah satu badak di

Asia yang paling banyak menyebar. Meski disebut badak jawa, binatang ini tidak terbatas hidup di Pulau Jawa saja, tetapi pernah hidup di seluruh Nusantara, sepanjang Asia Tenggara dan di India serta Tiongkok. Di Indonesia badak jawa tersebar di beberapa daerah.

Badak jawa tidak ada yang hidup di Penangkaran (tempat hidup buatan/eksitu) seperti Kebun-kebun Binatang atau Tempat-tempat Pelestarian Satwa (TPS) seperti Taman Safari Indonesia (Cisarua-Bogor). Kondisi ini mencerminkan kerentanan kehidupan dan keberadaan badak jawa, khususnya terhadap bila terjadinya bencana alam atau wabah hama penyakit. Mengingat badak jawa jumlahnya kurang dari 100 (seratus) ekor, penyebarannya terbatas di kawasan hutan Taman Nasional Ujung Kulon dan hanya ada di habitat alaminya, maka badak ini dikategorikan kedalam kelompok satwa langka yang menuju kepunahan. 
Badak jawa pernah hidup di hampir semua gunung-gunung di Jawa Barat diantaranya berada hingga diatas ketinggian 3000 meter diatas permukaan laut. Pada tahun 1960an, diperkirakan sekitar $20 \mathrm{~s} / \mathrm{d} 30$ ekor badak saja tersisa di TN Ujung Kulon. Populasinya meningkat hingga dua kali lipat pada tahun 1967 hingga 1978 setelah upaya perlindungan dilakukan dengan ketat, sebagian dilakukan dengan dukungan dari WWF-Indonesia. Sejak akhir tahun 1970-an, jumlah populasi badak jawa tampaknya stabil.

Berikut adalah jumlah populasi badak jawa tahun 2010-2013.

\begin{tabular}{|l|l|l|l|}
\hline \multirow{2}{*}{ Tahun } & \multicolumn{2}{|c|}{ Jenis Kelamin } & \multirow{2}{*}{ Jumlah } \\
\cline { 2 - 3 } & \multicolumn{1}{|c|}{ Jantan } & \multicolumn{1}{|c|}{ Betina } & \\
\hline 2010 & - & - & 32 \\
\hline 2011 & 22 & 13 & 35 \\
\hline 2012 & 29 & 22 & 51 \\
\hline 2013 & 35 & 23 & 58 \\
\hline
\end{tabular}

Sumber: http://www.wwf.or.id

Dari data diatas terlihat jumlah populasi badak jawa meningkat setiap tahunnya. Peningkatan populasi ini menjadi kabar baik disusul dengan dideklarasikannya Tahun Badak Internasional oleh Presiden Susilo Bambang Yudhoyono yang jatuh pada tanggal 22 September.

\subsection{Upaya Pemerintah dalam Konservasi Badak Jawa}

Di Indonesia, jika di Pulau Sumatera sangat sedikit diceritakan mengenai kehidupan badak jawa, tidak demikian dengan di Pulau Jawa. Kehidupannya sebelum kemerdekaan mungkin suatu kisah yang tragis, pernah menjadi binatang yang dibenci, tetapi kemudian diperlakukan sebagai binatang yang sangat dilindungi. Perubahan kebijakan terhadap badak nampak dengan mulai munculnya paradigma konservasi jenis hayati, yang mulai jenuh dengan penguasaan dan eksploitasi jenis-jenis pohon, misalnya jati, yang banyak mengganti hutan-hutan alam.

Upaya penegakan hukum terhadap pelaku perburuan dan perdagangan cula badak dan juga bagian-bagian tubuh satwa lain yang dilindungi UU, merupakan salah satu cara untuk menekan laju penurunan populasi badak dan juga satwa lain di Indonesia.

Untuk mengurangi bahkan menghapus sama sekali kegiatan-kegiatan perburuan di Indonesia terutama di Sumatra, maka dibentuklah unit-unit intelijen dan penegakan hukum atau Intelligence and Law Enforcement Unit (ILEU) yang bertugas:

1. Mengadakan operasi intelijen untuk membantu penangkapan pelaku perburuan liar dan perdagangan satwa ilegal,

2. Mengawal dan memastikan kasus-kasus kejahatan terhadap kehutanan terutama kasus perburuan dan perdagangan satwa yang dilindungi UU dapat diproses dan diajukan ke persidangan dan pelaku dikenakan sanksi atau hukuman yang sesuai dengan UU yang berlaku.

Kekuatan perlindungan badak bercula satu dapat ditunjukkan, melalui legalitasnya dalam UU No. 5 Tahun 1990. Sanksi hukuman yang berat bagi setiap orang, karena sengaja atau kelalaiannya, melakukan

pelanggaran, baik menangkap, membunuh, menyimpan, mengangkut, memperniagakan, baik di dalam Indonesia atau ke luar Indonesia, dan individu dalam keadaan hidup maupun mati, dan maupun bagian-bagian dari tubuh individunya. Dukungan kuatnya legalitas itu nampak efektif membuat orang tidak lagi berbuat perburuan liar terhadap badak. Perlindungan hidup badak masih menjadi tindakan utama dalam pengelolaan konservasi. Patroli pengamanan badak dan habitatnya dilakukan guna menjamin populasi aman dari gangguan-gangguan yang mematikan. Para petugas Balai TNUK yang ditempatkan pada pos-pos jaga melaksanakan secara rutin pada kawasan daratan maupun wilayah sekitarnya yang berupa perairan laut. Beberapa warga masyarakat setempat juga turut bergabung dalam pengamanannya, dalam tim-tim patroli, dengan nama Rhino Monitoring and Protection Unit (RMPU).

\subsection{Metode Penelitian}

\subsubsection{Desain Penelitian}

Untuk melakukan sebuah penelitian, diperlukan sebuah desain atau rancangan yang berisi rumusan tentang objek yang akan diteliti. Metode penelitian yang digunakan peneliti dalam penelitian ini adalah metode penelitian kualitatif. Merujuk pada permasalahan yang diangkat serta variabel yang tersedia, maka peneliti hanya melakukan analisa data berdasarkan data-data serta informasi yang dikeluarkan oleh WWF dan Pemerintah Indonesia dan diimplementasikan dengan teori-teori dalam kajian Hubungan Internasional.

\subsubsection{Teknik Pengumpulan Data}

Penelitian ini menggunakan teknik pengumpulan data melalui studi kepustakaan, penelusuran data online, dokumentasi, dan wawancara. Hal ini dikarenakan penelitian ini difokuskan pada peran suatu organisasi internasional dalam suatu isu lingkungan hidup dengan mengolah data-data yang diperoleh dari sumber yang relevan secara mendalam.

\subsection{Teknik Penentuan Informan}

Teknik Penentuan informan yang dipakai peneliti adalah dengan menggunakan teknik penentuan Purposive. Yaitu peneliti menentukan pihak-pihak informan berdasarkan tujuan, masalah dan variabel penelitian. Teknik yang digunakan adalah teknik wawancara sesuai dengan masalah yang akan diteliti. Berkaitan dengan WWF yaitu dalam hal ini peneliti bertemu dengan narasumber yang menjadi salah satu anggota WWF-Indonesia. Untuk mengetahui keadaan populasi Badak Jawa, peneliti menentukan informan 
dari pihak Taman Nasional Ujung Kulon yang merupakan satu-satunya tempat konservasi Badak Jawa di Indonesia.

\subsubsection{Teknik Analisa Data}

Dalam penelitian kualitatif ini, peneliti menganalisis data dengan menggunakan teknik reduksi data. Artinya, data-data yang diperoleh, baik melalui studi pustaka, penelusuran online dan wawancara, digunakan sesuai dengan keperluan penelitan berdasarkan dengan tujuan penelitian. Hal ini bertujuan supaya data yang digunakan berkorelasi dengan perumusan masalah yang telah dibuat. Penyajian Data, peneliti menyajikan data-data yang diperoleh dari hasil meneliti dan wawancara atau dari sumber-sumber internet sesuai dengan kebutuhan. Penarikan kesimpulan, peneliti menarik kesimpulan dari beberapa data yang disajikan baik data primer atau sekunder yang didapatkan dari informan yakni Pihak WWFIndonesia dan pihak Taman Nasional Ujung Kulon.

\subsubsection{Lokasi dan Waktu Penelitian \\ 3.4.5.1 Lokasi Penelitian}

Dalam penelitian ini penulis memperoleh data dan informasi yang bersumber dari berbagai tempat di bawah ini sesuai dengan kebutuhan penelitian, diantaranya:

1. Kantor WWF-Indonesia Ujung Kulon Project OfficeVilla Admiral Jalan Halmahera No. 09 Resort Lippo Carita, Km. 8 Banten.

2. Balai Taman Nasional Ujung Kulon Jl. Perintis Kemerdekaan No.51 Labuan, Serang, Pandeglang, Banten

3. Perpustakaan Universitas Komputer Indonesia Jalan Dipati Ukur No.116, Bandung

\subsubsection{Waktu Penelitian}

Penelitian ini dilaksanakan dalam kurun waktu delapan bulan terhitung dari bulan Januari sampai dengan bulan Agustus 2014.

\section{Hasil Penelitian dan Pembahasan}

4.1 Upaya World Wide Fund for Nature (WWF) dalam Konservasi Populasi Badak Jawa di Indonesia

World Wide Fund for Nature (WWF) sebagai organisasi non-pemerintah yang menangani masalah spesies langka yang salah satunya adalah spesies badak jawa. Upaya penyelamatan badak jawa dari kepunahannya terus dilakukan oleh WWF. Badak jawa juga tercantum dalam Appendix I CITES, yang merupakan indikasi dari spesies dengan jumlah yang sangat terbatas di alam dan terancam punah, bahwa setiap bentuk perdagangan dilarang. Oleh karena itu, upaya penyelamatan badak jawa dari ancaman perburuan harus terus dilakukan karena jumlahnya yang sangat terbatas.
Berikut terdapat program dan beberapa kegiatan yang dilakukan WWF-Indonesia sebagai bagian dari jaringan WWF Internasional dalam upaya konservasi badak jawa.

4.1.1 Upaya yang Telah Dilakukan World Wide Fund for Nature (WWF) dalam Konservasi Populasi Badak Jawa di Indonesia

1. Program Pelestarian Badak (RhinoCare)

2. Analisis Nutrisi dan Hormon Badak Jawa Melalui Kotoran

3. Monitoring Badak Jawa

4. Disease Surveillance

5. Manajemen Habitat

6. Penelitian tentang Badak Jawa

7. Program Pendampingan Produksi Patung Badak sebagai Souvenir khas Ujung Kulon

8. Program Pemberdayaan Masyarakat

9. Ekowisata yang Memperhatikan Eksistensi Badak Jawa

10. Pengamanan Badak

4.1.2 Upaya yang Belum Dilakukan World Wide Fund for Nature (WWF) dalam Konservasi Populasi Badak Jawa di Indonesia

Dalam Strategi dan Rencana Aksi Konservasi Badak Indonesia (SRAKBI) 2007-2017 yang ditetapkan dalam lokakarya yang dihadiri para pakar badak, pemerintah dan wakil sejumlah LSM lingkungan yang salah satunya adalah WWF, pada 2728 Februari 2006, salah satu strategi penyelamatan populasi badak jawa adalah membentuk satu tambahan populasi diluar habitat Nasional Ujung Kulon (second population/habitat) melalui translokasi setelah dilakukan identifikasi dan mengamankan habitat tambahan yang sesuai dan aman yang telah dikaji secara mendalam.

Untuk membentuk second habitat memerlukan waktu yang panjang dan persiapan yang matang. Kementerian Kehutanan dan stakeholder lain harus menyepakati wilayah mana yang tepat bagi habitat baru badak jawa. Kapasitas sumber daya manusia Taman Nasional Ujung Kulon dan mitra lain yang ikut berperan harus ditingkatkan. WWF-Indonesia mengharapkan 2017 second habitat dapat terlaksana.

4.2 Kendala yang dihadapi World Wide Fund for Nature (WWF) dalam Upaya Konservasi Populasi Badak Jawa di Indonesia

Video trap yang digunakan untuk monitoring badak jawa memiliki beberapa kelemahan seperti:

1. Perubahan Perilaku pada Badak Jawa

Video trap dapat digunakan dalam berbagai keperluan. Selain untuk mengetahui jumlah populasi, video trap dapat digunakan untuk mengetahui perilaku badak jawa, pakan, maupun daerah jelajah. Namun hal ini terkadang tidak dapat dilakukan karena adanya proses belajar pada satwa. Yahya (2002) menyebutkan salah satu hal yang 
menyebabkan hasil penelitian tidak sesuai dengan harapan adalah adanya proses belajar sehingga dengan sistem percobaan (kamera) sehingga badak segan untuk berbuat sesuatu yang wajar. Proses belajar yang terjadi pada badak jawa terhadap video trap sangat kecil. Namun hal ini sering terjadi pada setiap kegiatan yang melibatkan video trap. Pada tahun 2008, kamera miik WWF diseruduk oleh badak jawa hingga terjatuh dari tempatnya. Pada penelitian Yahya (2002), beberapa individu badak jawa sangat dekat dengan kamera atau trailmaster seolah ingin menyeruduk atau mencium alat percobaan. Pada penelitian ini, seekor badak jawa juga merespon kamera dengan berjalan mendekati kamera, lalu menundukkan kepala memamerkan cula, kemudian lari. Griffiths (1993) telah melakukan percobaan terhadap badak jawa, badak sumatra, dan harimau sumatra mengenai pengaruh pemasangan kamera trap terhadap perilaku spesies target dan menyimpulkan bahwa jarak maksimun antara target dan kamera adalah 3,5 meter.

2. Rentan Terhadap Cuaca yang Tidak Bersahabat dan Pencurian

Jika ditinjau dari berat dan dimensi tiap unit video trap, maka video trap tergolong ringan dan sangat praktis. Namun, selama di lapangan video trap harus terlindung dari kemungkinan rusak akibat hujan lebat, ataupun kemasukan air saat menyebrangi sungai untuk menghindari terjadinya kerusakan. Hal inilah yang menjadi kekurangan pada video trap yang digunakan pada saat ini.

Selain kendala teknis, ada juga kendala non-teknis yang dihadapi WWF dalam upaya konservasi badak jawa yaitu adanya persaingan ekologi badak jawa dan banteng di Taman Nasional Ujung Kulon. Kawasan Taman Nasional Ujung Kulon merupakan habitat yang cocok untuk badak jawa dan banteng karena menyediakan kebutuhan spesies tersebut, baik jenis pakan, tempat berlindung, air, mineral maupun tempat berhubungan sosial. Pada kenyataannya, kondisi habitat banteng dan badak jawa mempunyai kualitas dan kuantitas yang terbatas. Beberapa temuan lapangan dari beberapa peneliti menunjukkan adanya indikasi persaingan badak jawa dan banteng. Sebuah penelitian menyatakan bahwa indikasi persaingan dapat dilihat dari banyaknya jenis tumbuhan pakan yang sama, adanya dominasi tumbuhan tertentu yang tidak menguntungkan bagi tersedianya jenis tumbuhan pakan badak jawa dan jalur lintasan yang tumpang tindih.

\subsection{Rekomendasi yang diberikan oleh World Wide Fund for Nature (WWF) untuk Pemerintah Indonesia}

Menurut Anwar Purwoto, Direktur Program Kehutanan, Spesies Terestrial dan Air Tawar WWFIndonesia, upaya untuk menciptakan habitat yang aman bagi badak merupakan tugas berat bagi pemerintah karena itu kerjasama dan dukungan dari berbagai pihak sangat dibutuhkan. Peran serta masyarakat juga diharapkan mampu mendorong efektifitas upaya pencegahan terhadap badak, khususnya perdagangan liar cula badak. Selain itu, WWF-Indonesia juga akan terus mendukung penegakan hukum bagi tindak kejahatan perusakan lingkungan hidup, khususnya perburuan dan perdagangan satwa-satwa langka seperti badak.

Selain itu menurut Nazir Foead, Direktur Konservasi WWF-Indonesia, bahwa perlu kerjasama yang baik antar negara sebaran badak untuk memutus mata rantai jaringan perburuan internasional. Selain itu, dukungan semua pihak termasuk komunitas global dibutuhkan bukan hanya untuk mengatasi maraknya perburuan dan perdagangan badak Indonesia tetapi juga dalam memulihkan dan mendorong naiknya populasi satwa tersebut di alam.

WWF juga memberi masukan pada pola pengelolaan kolaboratif taman nasional dengan menegaskan posisi dan peran masyarakat, satu aktor kunci efektivitas pengelolaan kawasan. Lebih lanjut lagi, dilakukan pemetaan partisipatif atas lokasi yang bernilai ekologi, sosial, kultural dan spiritual penting bagi masyarakat.

\section{Kesimpulan dan Saran \\ 5.1 Kesimpulan}

Berdasarkan hasil penelitian yang diperoleh, maka peneliti menyimpulkan bahwa:

1. WWF sebagai salah satu Organisasi Internasional memainkan peranan penting di Indonesia, khususnya dalam upaya konservasi populasi badak jawa. WWF-Indonesia sebagai bagian dari WWF Internasional terdorong untuk melakukan berbagai program dan kegiatan yang dilakukan WWF menunjukkan bahwa WWF menaruh perhatian dalam fenomena kepunahan badak jawa di Indonesia.

2. Dalam upaya konservasi populasi badak jawa di Indonesia, WWF-Indonesia menghadapi beberapa kendala. Kendala tersebut dibagi menjadi kendala teknis dan kendala non teknis. Kendala teknis terkait dengan peralatan yang digunakan untuk kegiatan monitoring badak jawa seperti video trap. Banyak kekurangan pada video trap yang digunakan yaitu biaya yang tinggi, adanya perubahan perilaku pada badak jawa yang menyebabkan rusaknya video trap dan rentan terhadap cuaca yang tidak bersahabat serta pencurian. Sedangkan kendala non teknis yang dihadapi WWF-Indonesia adalah adanya persaingan ekologi badak jawa dan banteng di Taman Nasional Ujung Kulon. Jumlah dan pertumbuhan populasi banteng jauh lebih besar daripada badak jawa yang stagnan dan populasi banteng memiliki peluang lebih besar untuk terus bertambah. Pertambahan populasi banteng ini tentu saja akan mempengaruhi 
(mengurangi) daya dukung hutan bagi kedua jenis satwa ini, terutama bagi badak jawa.

3. Sudah 50 tahun WWF-Indonesia bekerjasama dengan pemerintah Indonesia khususnya untuk konservasi badak jawa. Untuk mencapai tujuan organisasinya, WWF memberi rekomendasi atau masukan kepada pemerintah Indonesia terkait dengan konservasi satwa ini yaitu bahwa upaya untuk menciptakan habitat yang aman bagi badak merupakan tugas berat bagi pemerintah oleh karena itu kerjasama dan dukungan dari berbagai pihak sangat dibutuhkan. Peran serta masyarakat juga diharapkan mampu mendorong efektifitas upaya pencegahan terhadap badak, khususnya perdagangan liar cula badak. Selain itu, WWF juga memberi masukan pola pengelolaan kolaboratif taman nasional dengan menegaskan posisi dan peran masyarakat, satu aktor kunci efektivitas pengelolaan kawasan. Lebih lanjut lagi, dilakukan pemetaan partisipatif atas lokasi yang bernilai ekologi, sosial, kultural dan spiritual penting bagi masyarakat.

4. Program-program serta kegiatan-kegiatan yang dilakukan dalam rangka untuk mencapai tujuan, telah menunjukkan hasil bahwa adanya peningkatan jumlah populasi badak jawa di Indonesia. Dengan demikian, peran WWF cukup signifikan dalam upaya konservasi badak jawa di Indonesia.

\subsection{Saran}

Berdasarkan kesimpulan di atas, peneliti memberikan saran bagi berbagai pihak yang terlibat dalam kegiatan konservasi badak jawa di Indonesia melalui skripsi ini, sebagai berikut:

1. Untuk WWF-Indonesia, upaya konservasi badak jawa harus terus ditingkatkan dengan berbagai program atau kegiatan yang efektif agar satwa ini dapat terus bertahan. Selain itu, WWF-Indonesia harus terus menjaga hubungan baik dengan pihakpihak yang ikut terlibat dalam upaya konservasi satwa ini.

2. Untuk Pemerintah, diharapakan fenomena kepunahan badak jawa ini mendapat perhatian serius. Indonesia sebagai satu-satunya negara yang menjadi tempat tinggal badak jawa, harus menjaga agar satwa yang terancam punah ini dapat bertahan hidup. Pemerintah diharapkan dapat membuat program yang komprehensif dan terintegrasi baik di tingkat kabupaten, provinsi, maupun nasional.

3. Untuk Balai Taman Nasional Ujung Kulon, agar terus mensosialisasikan kepada masyarakat khususnya warga di sekitar Taman Nasional Ujung Kulon untuk turut serta dalam upaya konservasi satwa ini dengan tidak melakukan ekspoitasi sumber daya alam di sekitar kawasan Taman Nasional Ujung Kulon yang merupakan habitat badak jawa. Balai Taman Nasional Ujung Kulon juga harus menyadarkan masyarakat bahwa pentingnya melestarikan satwa ini karena hilangnya badak jawa ini berarti tidak memberikan kesempatan kepada anak cucu kita untuk dapat menikmatinya dan memanfaatkannya bagi dukungannya terhadap kualitas kehidupan manusia secara berkelanjutan.

4. Untuk masyarakat luas, agar turut serta melestarikan badak jawa baik itu dengan memberikan donasi maupun ikut serta dalam program atau kegiatan yang dicanangkan oleh pemerintah atau dari LSM-LSM lingkungan seperti WWF.

\section{Acuan Buku}

Alikodra, Hadi. 2013. Teknik Konservasi Badak Indonesia. Tangerang: Literati

Bennet, Alvin LeRoy. 2002. International Organizations: Principles and Issues. New Jersey: Prentice Hall.

Archer, Clive. 2001. International Organization 3rd Edition. London: Rouledge

Dinerstein, Eric. 2003. The Return of the Unicorns; The Natural History and Conservation of the Greater One-Horned Rhinoceros. New York: Columbia University Press

Perwita, A.A Banyu, dan Yanyan Moch. Yani. 2005. Pengantar Ilmu Hubungan Internasional. Bandung: PT Remaja Rosdakarya.

Rudy, Teuku May. 2002. Hukum Internasional 2. Bandung: PT. Refika Aditama.

Vedder, Anton (ed). 2007. NGO involvement in International Governance and Policy: Source of Legitimacy. Netherland: Martinus Nijhoff Publisher.

\section{Acuan dari skripsi}

Prabu Putra, Rasuani, 2012. Kerjasama Indonesia dengan World Wide Fund For Nature (WWF) dalam Menanggulangi Kepunahan Badak di Ujung Kulon. Universitas Padjajaran: Tidak Diterbitkan

Zannah, Syarifatul. 2014. Peran World Wide Fund For Nature (WWF) dalam Konservasi Gajah Sumatera di Taman Nasional Tesso Nilo, Riau. Universitas Mulawarman: Tidak Diterbitkan.

\section{Acuan dari jurnal}

Arismunandar. 2002. WWF Indonesia 1962 - 2002. Melestarikan Alam Indonesia dengan Menyejahterakan Manusianya. 1-4.

Acuan dari website

Badak Jawa. Melalui http://www.wwf.or.id/ Diakses pada tanggal 17 Maret 2014. 